\title{
Development and induction of bacteria-associated galls on Prionitis lanceolata (Rhodophyta)
}

\author{
Kirk Apt, Aharon Gibor \\ Department of Biological Sciences, University of California, Santa Barbara, California 93106, USA
}

\begin{abstract}
Gall formation associated with bacteria on Prionitis lanceolata (Harv.) Harv. occurs if the causative agent comes into direct contact with internal medullary tissue via a wound site. Gall tissue originates in the medullary region and forms a unique dense compact tissue. Expansion of the gall ruptures the outer layers of normal tissue and exposes the growth. Bacteria-like particles were found in living gall tissue that were capable of inducing gall formation on uninfected thalli. But no bacteria isolated were capable of inducing gall formation. The role of bacteria in gall formation is still not clear.
\end{abstract}

\section{INTRODUCTION}

The association of bacteria with abnormal tissue growths (galls) on marine macroalgae has been reported for many years (Schmitz 1892, Brand 1897, Chemin 1927, 1931, 1932, 1937, Cantacuzene 1928a, b, 1930, Starmarch 1930, Lami 1946, Felicini \& Perrone 1972, McBride et al. 1974, Tsekos 1982). At least 20 species of red and brown algae have been reported to bear bacteria-associated galls (Apt 1988). These growths are characterized by host cell hypertrophy and hyperplasy producing abnormal tissue proliferation, with the associated bacteria found primarily in the intercellular spaces of the cells composing the gall growth. The gross morphology of bacterial galls has been described by many of the above authors; however little is known regarding gall development or the interactions between host and bacteria.

The purpose of this study was to examine gall development and to characterize the causative agent of bacteriaassociated galls on Prionitis lanceolata (Harv.) Harv.

\section{MATERIALS AND METHODS}

Prionitis lanceolata with and without galls were collected primarily from Pigeon Pt, San Mateo Co.; Piedros Blancas Pt and Cayucos Pt, San Luis Obispo Co., California, USA. Thalli collected from nature were stored until use in 50 gallon (190 1) tanks with rapidly flowing seawater [2 to $3 \mathrm{gal}$ ( 7.5 to $11 \mathrm{l}$ ) $\mathrm{min}^{-1}$ ] under a shade screen. Thalli maintained under these conditions remained healthy and growing for over $1 \mathrm{yr}$.

Thalli collected from nature used for inoculations were kept in separate 2 gal (7.5 l) tanks with rapidly flowing seawater [0.2 gal $\left.(0.75 \mathrm{l}) \mathrm{min}^{-1}\right]$ for 1 mo to confirm that no galls were present. Prior to inoculation thalli were thoroughly cleaned of all visible epiphytic organisms and debris. Surface sterilization had no significant effect and was not generally used prior to infection. Wound sites were infected by shallow lacerations ( 0.5 to $1.0 \mathrm{~mm}$ deep and several $\mathrm{cm}$ long) with a sterile razor blade or injected with a needle. Inoculum was prepared from excised galls by surface sterilization ( $70 \% \mathrm{EtOH}, 10 \%$ bleach or $5 \%$ hydrogen peroxide) and homogenation of ca 10 galls with a mortar and pestle or tissue grinder in $1 \mathrm{ml}$ of sterile seawater. Thalli to be infected were bathed in $10 \mathrm{ml}$ of inoculum for several hours or injected with the inoculum directly into internal tissue with a hypodermic syringe, then placed in a small tank with no water motion for $24 \mathrm{~h}$.

Laboratory cultures of Prionitis lanceolata were started from tetraspores. Spores were collected from surface-cleaned thalli and allowed to release and settle in a petri dish overnight. Spores were collected, rinsed twice in sterile seawater and transferred to small petri dishes in PES (Provasolis' Enriched Seawater) medium (McLachlan 1973). Medium was changed weekly and developing thalli transferred to larger containers. $P$. lanceolata cultured in the laboratory were infected by injecting the supernatant from homogenized gall tissue into internal tissue with a hypodermic syringe, as 
described above. Size fractions of homogenized gall tissue were produced by filtering through a series of filters $(50,10,0.45 \mu \mathrm{m})$. Each fraction was injected separately into uninfected thalli and maintained as previously described above.

Specimens for light microscopy were preserved in $3 \%$ formalin-seawater, sectioned on a cryostat and stained with $1 \%$ aniline blue

Specimens for scanning electron microscopy (SEM) were prepared by fixation in 3\% gluteraldehyde, $1 \%$ formaldehyde, $90 \%$ seawater for $1 \mathrm{~h}$, rinsed in distilled water, dehydrated in a graded acetone series, critically point dried and coated with gold-palladium. Photographs were taken on a Hitachi S415-A scanning electron microscope.

\section{RESULTS}

\section{Field observations}

Galls found on specimens of Prionitis lanceolata collected from nature were frequently associated with obviously damaged portions of the thallus (Fig. 1), Damage consisted of torn blades or broken branches which had exposed internal tissues. Approximately $45 \%$ of galls examined on field specimens ( $n=360$ ) were found on such areas. Normal host tissue directly adjacent to a gall showed no visible sign of detrimental effects with regard to pigmentation or tissue structure as compared to uninfected portions of the same thallus. When present, galls were found in numbers as high as 15 per thallus, but typically less than 5. Thalli bearing galls were found consistently in the low intertidal surge zones. Thalli in the mid to high intertidal rarely bore galls. Geographically, thalli with galls were distributed irregularly; some localized areas contained large numbers of galls, while other areas as near as $20 \mathrm{~m}$ contained few galls. In general wherever Prionitis Ianceolata was present, close examination revealed at least a few thalli bearing galls.

\section{Infection studies}

The specific causative agent of gall formation was found to be a living infectious particle, which was present inside gall tissue and transferable (Table 1). Homogenized gall tissue, but not homogenized normal tissue, was able to initiate gall formation, when introduced into internal tissue through a wound site. Gall material which was autoclaved prior to infection did not induce gall formation. Size fractionation of homogenized gall tissue (Table 2) indicated that the infectious agent was greater than $0.45 \mu \mathrm{m}$ in size.
A variety of bacteria were isolated from the internal tissues of surface-sterilized gall tissue. These bacteria could be cultured on modified 2216 medium (Johnson 1968 ) at $10 \%$ concentration. At medium concentrations above $10 \%$ internal gall bacteria were inhibited. Aqueous gall extracts $\left(50 \mathrm{~g} 100 \mathrm{ml}^{-1}\right)$ at concentrations above $1 \%$ also inhibited growth of gall bacteria. Typically only 1 to 3 morphologically distinct bacteria were isolated. However, no bacterial isolates, singly or in combination, were capable of initiating gall formation. On several occasions individual isolates were able to induce small numbers of galls, but unfortunately these bacteria could not be maintained in culture.

\section{Gall development}

Normal tissue was divided into 3 regions. An outer cortical region was composed of small diameter (10 to 20 $\mu \mathrm{m})$, isodiametric, red pigmented cells arranged in distinct anticlinal rows. A subcortical region 5 to 10 cells thick contained enlarged (up to $50 \mu \mathrm{m}$ ), colorless, isodiametric cells and an internal medullary region consisted of colorless, densely packed filamentous cells.

It took ca 1 to 2 mo after inoculation with homogenized gall tissue for a macroscopically visible growth to appear (Fig. 2) on previously uninfected thalli collected from nature. Following wounding the thallus responded by healing over the damaged tissue. Exposed cortical and medullary cells began dividing and formed a new epidermal layer. The effect was apparently to trap the infectious agent in the internal

Table 1. Prionitis lanceolata. Results of infection test on thalli collected in nature

\begin{tabular}{|lcc|}
\hline & $n$ & $\begin{array}{c}\text { No. of } \\
\text { galls }\end{array}$ \\
\hline Normal thalli (no homogenate) & 30 & 0 \\
Wounded thalli (no homogenate) & 40 & 3 \\
Normal + gall homogenate & 30 & 0 \\
Wounded + gall homogenate & 40 & 575 \\
Wounded + gall homogenate (autoclaved) & 20 & 2 \\
Wounded + vegetative homogenate & 20 & 3 \\
\hline
\end{tabular}

Table 2. Prionitis lanceolata. Induction of gall development by different size fractions of homogenized gall tissue. $n=20$

\begin{tabular}{lc|}
\hline Size & No. of galls \\
\hline Unfractionated & 98 \\
$<50 \mu \mathrm{m}$ & 63 \\
$<10 \mu \mathrm{m}$ & 25 \\
$<0.45 \mu \mathrm{m}$ & 0 \\
\hline
\end{tabular}




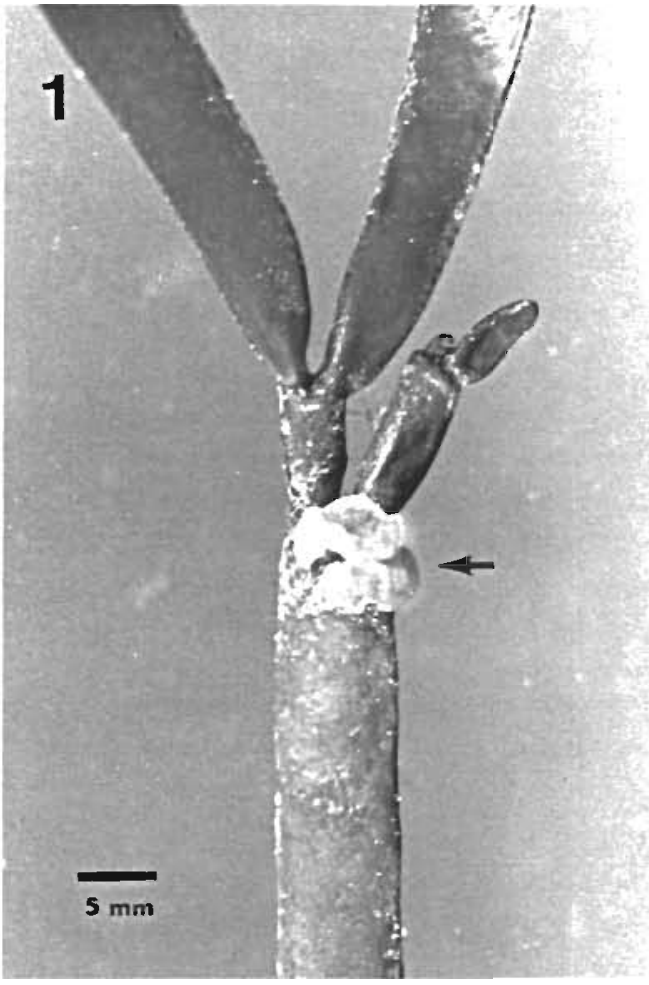

4
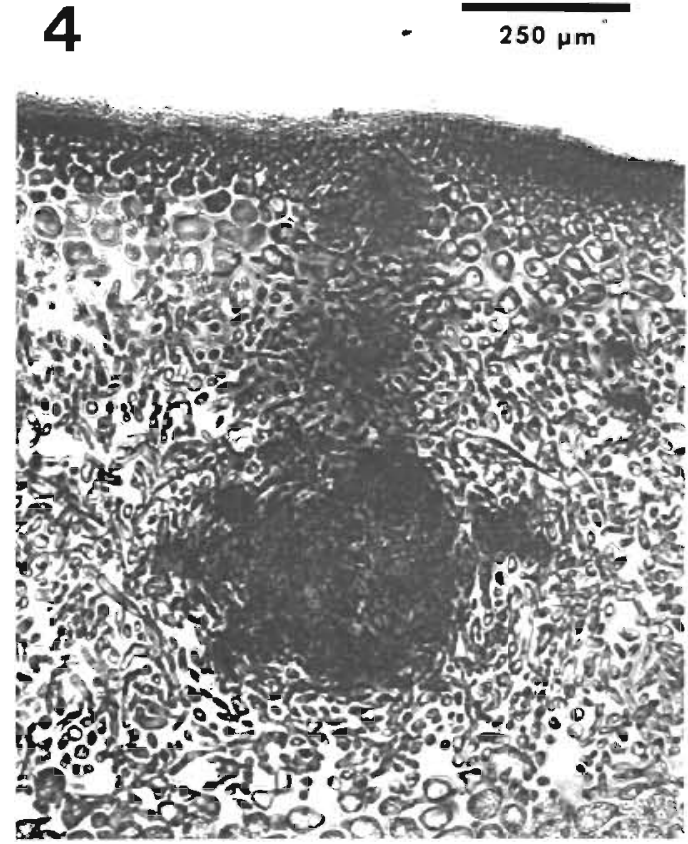
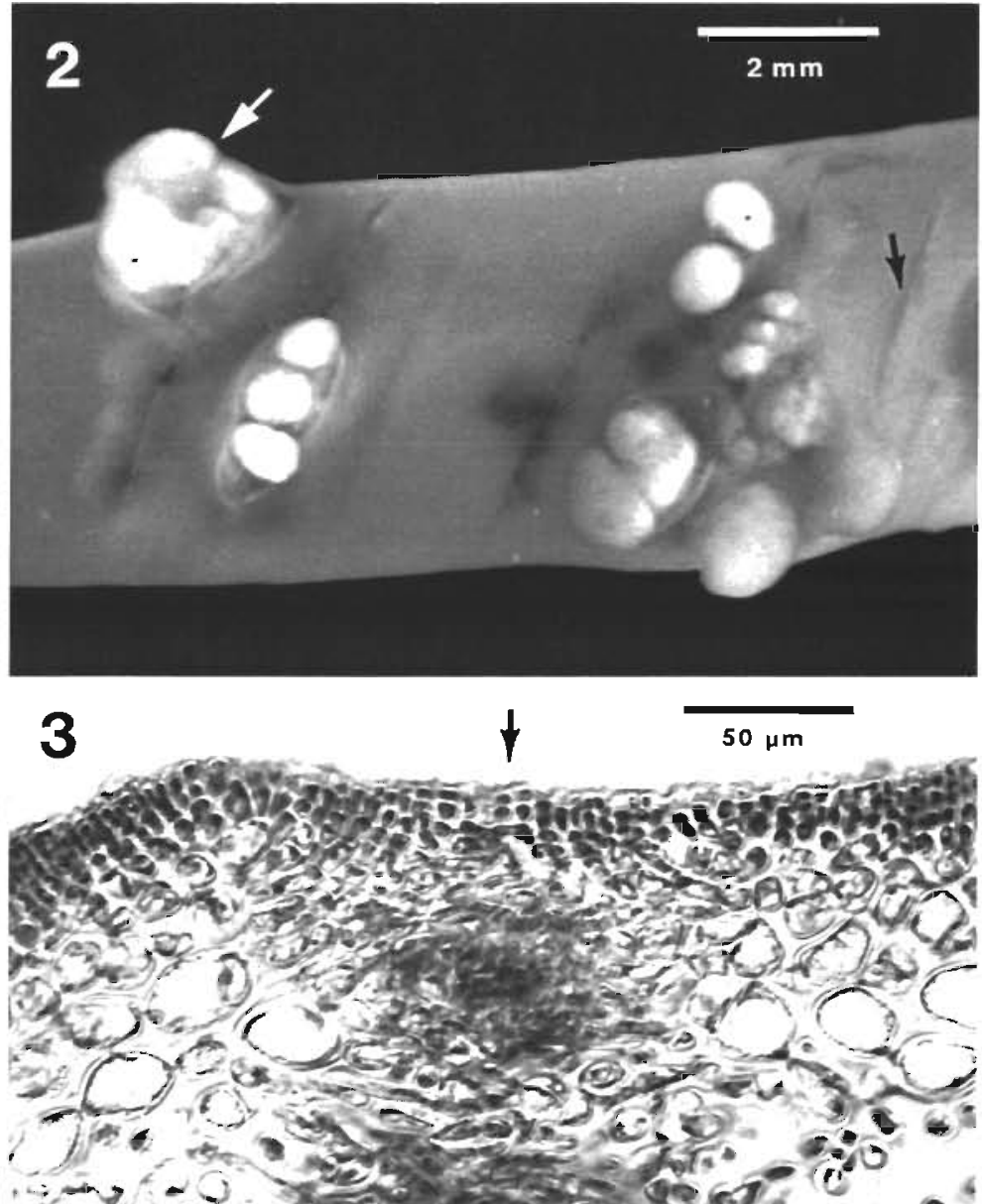
$\therefore, 0.0$.

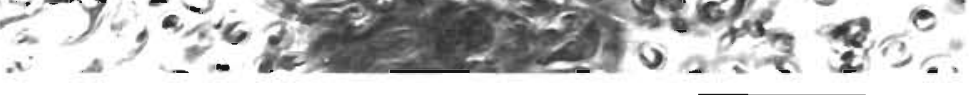

\section{5}

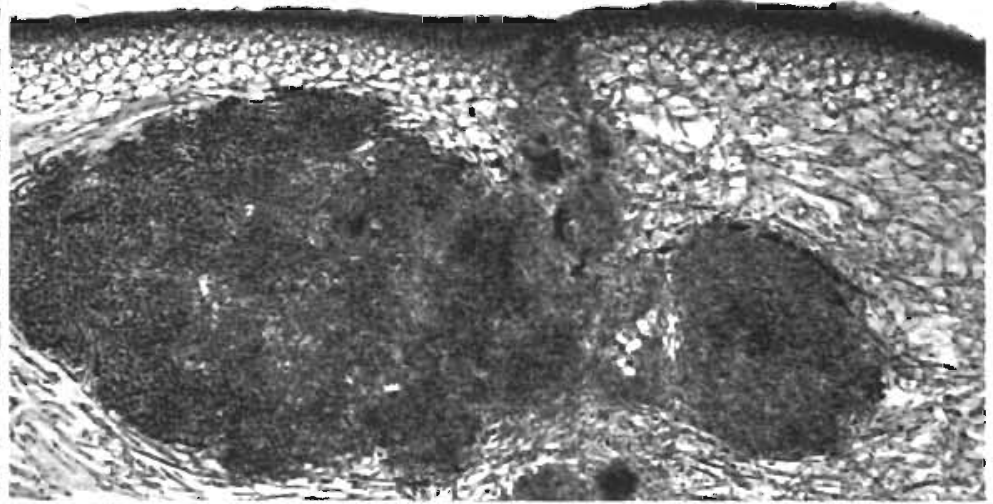

Figs. 1 to 5. Prionitis lanceolata with bacteria-associated galls. Fig. 1. Thallus collected from nature bearing a single bacteriaassociated gall (arrow). The gall formed on a broken branch where 2 new branches also developed. Each of these 2 branches has in turn been broken and is regenerating new branches. Fig. 2. Thallus infected in the laboratory by inoculation with homogenized gall tissue. Numerous galls (white arrow) are rupturing through the cortical tissue at the scars (black arrow) where inocolum was applied. Fig. 3. Cross section through scar area (arrow) where cortical and subcortical cells are less organized. Fig. 4. Earliest detectable stage of gall development where a small group of medullary cells are dividing, forming a dark-staining mass. Fig. 5 . Early stage of gall development where a growing mass of dark-staining gall tissue has formed in the medullary region 
tissues. After healing, a scar area (Fig. 3) remained visible. In cross section the subcortical cells were less organized and did not show a gradual transition from outer cortex to medulla. The initial stages of gall development were visible as a small clump of cells (Fig. 4) deep in the medulla. As development continued a large portion of the internal area became occupied by the growing gall tissue (Fig. 5) displacing the normal medullary cells. The result was that the elongated filamentous cells and large intercellular spaces characteristic of medullary tissue became a dense compact tissue composed of small diameter (10 to $20 \mu \mathrm{m})$, intensely staining, irregularly shaped cells with bacteria present in the intercellular spaces (Fig. 6). At this stage gall tissue contained dark red pigmentation, while normal medullary tissue was colorless. The expansion of gall tissue eventually displaced the cortical and epidermal layers upward. Rupture of the cortical and epidermal layers exposed the subsurface gall tissue. The gall tissue then expanded through the opening (Fig. 2,7 and 8). External proliferation of gall tissue produced a mushroom-shaped structure (Fig, 9). Cells composing the gall tissue remained small in diameter and irregularly shaped, but the red pigmentation decreased to a faint pink or yellow. In most cases gall tissue was totally undifferentiated, but on occasion a gall in early development or sometimes later development would have a thin but normal epidermal layer present. The epidermal layer was able to continue its development unaffected by the underlying gall tissues,
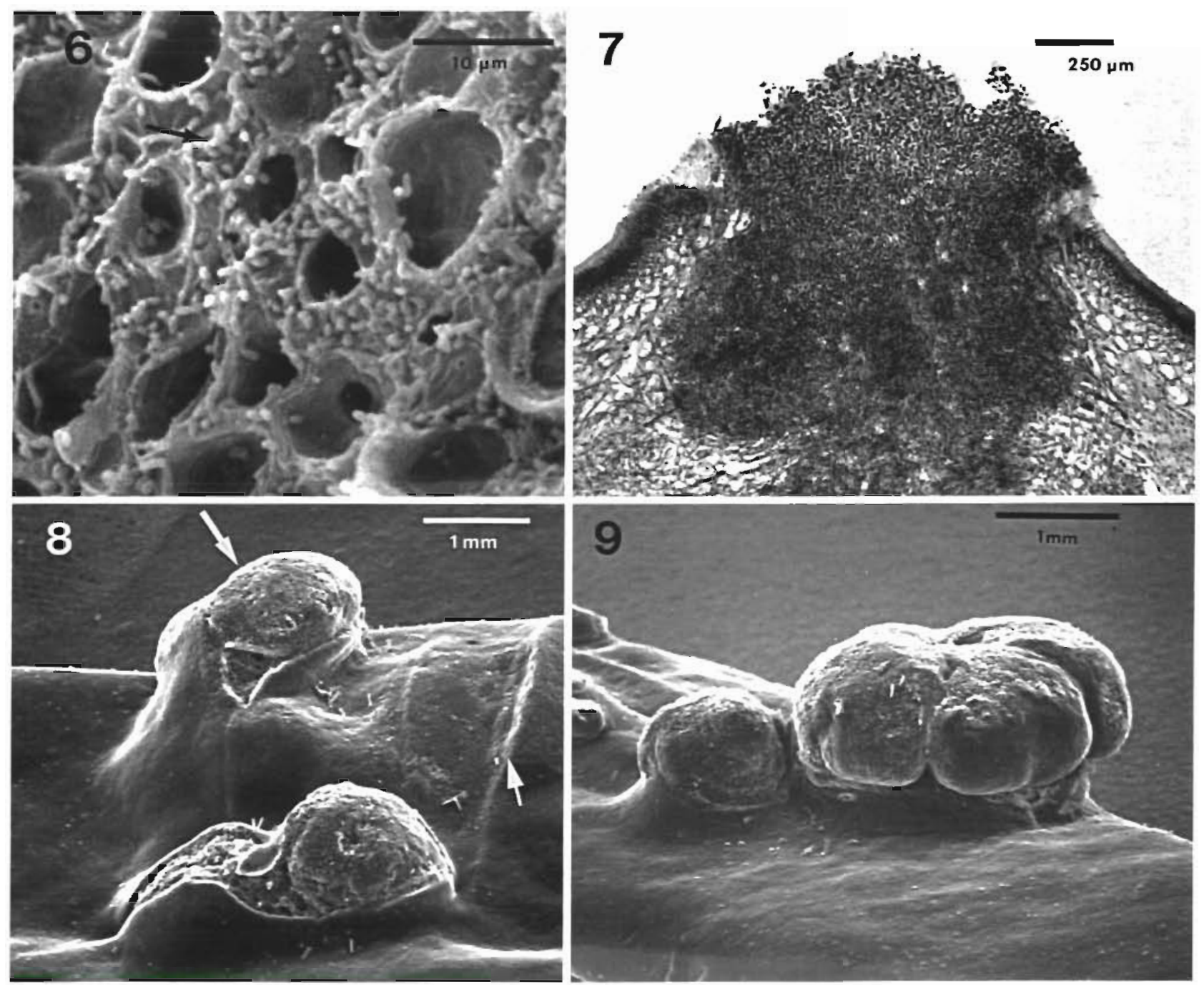

Figs 6 to 9. Prionitis lanceolata. Laboratory-infected bacteria-associated galls. Fig. 6. SEM of gall tissue cross section. Numerous bacteria (arrow) are present as short rods. The large holes are cells of the gall tissue. Fig. 7 . Cross section of thallus. Expansion of gall tissue has displaced and ruptured the cortical tissue, exposing the gall tissue. Fig. 8. SEM of developing gall. Gall tissue (large arrow) has split the cortical tissue and is emerging. Scar areas (small arrow) are still visible nearby. Fig. 9. SEM of fully developed gall. Exposed gall tissue has formed a mushroom-like structure 
however in the majority of cases the epidermis was not present. When an exposed gall was excised the underlying tissue continued to proliferate and reformed a new gall. Secondary gall development at a site distant from the original wound and inoculation was never observed. Gall development took place only at the inoculation site.

Gall development on laboratory cultured thalli took between 1 and 2 mo after inoculation for a macroscopically visible growth to appear. Sites of inoculation developed into galls within 1 mo when inoculum was injected within $1 \mathrm{~cm}$ of a growing tip. In other areas farther from the tip, the appearance of galls required up to $2 \mathrm{mo}$. Over $90 \%$ of all inoculation sites formed galls.

\section{DISCUSSION}

The role of bacteria as the causative agent in gall formation has not been clearly established. This study provides evidence that a heat-sensitive bacterial-sized factor (between 10 and $0.45 \mu \mathrm{m}$ ), present in living gall tissue, can induce similar growths on previously uninfected hosts. Unfortunately no bacteria have yet been isolated which are capable of inducing gall formation. The elimination of infectivity with size fractions below $0.45 \mu \mathrm{m}$ discounts the possibility that virus-like particles are the causative agents. Moreover virus-like particles have not been observed ultrastructurally (McBride et al. 1974). It is also not likely that the growth results from a transfer of tumorous Prionitis lanceolata cells from one thallus to another. The $10 \mathrm{um}$ fraction is below the size of the smallest diameter cortical cells and no intact cells were observed in the fractions below $10 \mu \mathrm{m}$.

Chemin (1937), reporting on red algal tumors, was unable to isolate a causative bacterium from bacteriaassociated growths on Cystoclonium purpureum. Cantacuzene (1930) reported having isolated a bacterium that induced galls on Saccorhiza bulbosa, however the bacterium was only partially characterized, and there was no indication as to the purity of the isolate. This same bacterium was also considered by Cantacuzene (1930) to cause abnormal growths on Chondrus crispus and certain other red algae.

In this study bacteria were observed only in the intercellular spaces. This has been previously established at the light and ultrastructural levels for Prionitis lanceolata, Polyneuropsis stolonifera (McBride et al. 1974) and Gigartina teedii (Tsekos 1982). These studies found no evidence that bacteria were intracellular. Bacteria were found primarily in the intercellular matrix or partially embedded in the cell wall.

Gall formation is a tissue-specific phenomenon. Only cells in the medullary region were involved in gall development. Epidermal and cortical cells were not directly involved in cell proliferation. This has also been reported for Saccorhiza bulbosa, Chondrus crispus, Cystoclonium purpureum (Cantacuzene 1930) and previously for Prionitis lanceolata (McBride et al. 1974).

Gall tissue is composed of cells with an unique morphology that bear little resemblance to normal tissue. Gall tissue is more than just a proliferation of medullary tissue as described by McBride et al. (1974). Medullary cells have a distinct filamentous morphology which is lost after infection. Gall tissue characteristically is composed of unorganized, irregularly shaped, smalldiameter cells.

Exposure of internal medullary tissue through a wound site or some other means was necessary for gall formation. Gall development only occurred if the causative agent came into direct contact with the medullary cells. It is not clear what unique properties medullary cells possess allowing them to proliferate after infection. Cantacuzene (1930) also found a wound site necessary for gall formation on Saccorhiza bulbosa. He further speculated that Heleyon pellucidum, a marine mollusk, could act as a vector for infection by bacteria via its feeding behavior. It is not known how the causative agent is transmitted for Prionitis lanceolata galls.

Wound sites also provide entry points for bacteria in many terrestrial galls (Riker et al. 1946). Galls produced on olive (genus Olea) by Pseudomonas savastanoi have several characteristic similar to Prionitis lanceolata galls. A wound site was necessary for infection; possible wounds included leaf scars, pruning wounds or freezing injuries. P. savastanoi, upon entry, migrated into internal tissues. Cells adjacent to bacteria begin dividing and form a callus-like mass of more or less undifferentiated tissue. It is known that the infecting bacteria carry a plasmid that contains a gene for indoleacetic acid (IAA) synthesis (Nester \& Kosuge 1981). Production of IAA by the bacteria disrupts the balance of plant growth regulators and induces abnormal cell divisions. A similar phenomenon involving an unknown growth substance may occur in P. lanceolata galls. Intercellular bacteria could be providing a growth regulating substance which is inducing cell proliferation.

Acknowledgements. The authors thank Drs M. Moseley, B. Sweeney and M. Neushul for their advice and assistance. This work was partially supported by the University of California Marine Biotechnology Training Program.

\section{LITERATURE CITED}

Apt, K. (1988). Galls and tumor-like growths on marine macroalgae. Dis. aquat. Org. 4: 211-217

Brand, F. (1897). Uber Chantransia und die einschlägigen Formen der bayerischen Hochebene. Hedwigia 36: 300-319 Cantacuzene, A. (1928a). Structure anatomique des tumeurs 
bactériennes de Saccorhiza bulbosa. C. r. Séanc. Soc. Biol. Paris 99: 1715-1717

Cantacuzene, A. (1928b). Tumeurs bacteriennes des thallus de Saccorhiza bulbosa. C. r. Séanc. Soc. Biol. Paris 99: 565-566

Cantacuzene, A. (1930). Contribution à l' étude des tumeurs bactériennes chez les algues marines. Thèse presentée à la Faculté des Sciences de I' Université de Paris

Chemin, E. (1927). Action des bactéries sur quelques algues rouges. Bull. Soc. bot. Fr. 74: 441-451

Chemin, E. (1931). Sur la presence de galles chez quelques floridées. Rev. Algol. 5: 315-325

Chemin, E. (1932). Sur l'existence des galles chez Ceramium rubrum. C.r. Séanc. Soc. Biol. Paris 109: 135-151

Chemin, E. (1937). Rôle des bactéries dans la formation des galles chez les Floridales. Annls Sci. nat. Bot. 19: 61-71

Felicini, G. P., Perrone, C. (1972). Sulla formazione di galle nella rigenerazione di Pterocladia capillacea (Gmel.) Born. et Thur. in cultura. G. Bot. Itâl. 106. 351-358

Johnson, P. (1968). A new medium for maintenance of marine bacteria. J Invert. Pathol. 11. 144

Lami, R. (1946). Notules d' algologie marine X. Quelques galles bactériennes d'algues marines. Bull. Lab. marit. Dinard 27: 26-30

McBride, D. L., Krugens, P., West, J. A. (1974). Light and electron micruscupe observations on red algal galls. Protoplasma 79: 249-264

McLachlan, J. (1973). Growth media. In: Stein, J. R. (ed.) Handbook of phycological methods: culture methods and growth measurements. Cambridge Univ. Press, Cam. bridge, p. 25-51

Nester, E. W., Kosuge, T (1981). Plasmids specifying plant hyperplasias. Ann. Rev. Microbiol, 34: 532-541

Riker, A. J., Spoerl, E., Gutsche, A. E. (1946). Some comparisons of bacterial plant galls and of their causal agents. Bot. Rev. 12: $57-82$

Schmitz, F. (1892). Über knöllchenartige Auswüchse an den Sprossen einiger Florideen. Bot. Ztg 50: 624-630

Starmarch, K. (1930). Die Bacteriengallen auf manchen Süßwasserarten der Gattung Chantransia. Acta Soc. Bot. Pol. 7: 435-460 (Polish. German summary)

Tsekos, I. (1982). Tumour-like growths induced by bacteria in the thallus of a red alga. Gigartina teedi (Roth) Lamour. Ann. Bot. 49: 123-126

Responsible Subject Editor: Professor S. Bonotto; accepted for printing on November 30, 1988 